\title{
Revision of acritarchs and prasinophyte algae from the lower Silurian of Belgium
}

\author{
GARY L. MULLINS \\ Department of Geology, University of Leicester, University Road, Leicester LE1 7RH, UK.
}

\begin{abstract}
The type acritarch and prasinophyte algal material of Stockmans \& Willière (1963), from the Silurian of the Courtrai region, Belgium, has been re-examined. Revised descriptions for the holotypes of several type species are given, which detail the greater morphological diversity recognized. Four new combinations are proposed (Buedingiisphaeridium parveroquesi, Dictyotidium deflandrei, Helosphaeridium echinodermum and Multiplicisphaeridium pentagonale). Micrhystridium? radians is provisionally retained, although it is probable that this species should be referred to a new, unrecognized genus (it possesses a pylome and spinose, simple and branched processes). The synonymy of Diexallophasis denticulata and Diexallophasis remota (proposed by Playford, 1977) is rejected, as the latter has broader-based and more robust processes. The generic assignment of Diexallophasis mucronata is confirmed. Several of the taxa proposed by Stockmans \& Willière have been re-illustrated to show clearly the features of taxonomic importance. These descriptions and illustrations will enable the reliable recognition of these taxa in contiguous sections elsewhere, and will help to form the basis of future population studies. J. Micropalaeontol. 21(1): 87-94, May 2002.
\end{abstract}

\section{INTRODUCTION}

The work of Stockmans \& Willière (1963) on the acritarchs of the Courtrai region of Belgium was one of the pioneering studies on Silurian acritarchs. The material they examined was from a borehole, and all of the acritarchs illustrated were from a single level (188.50 m; dated as Tarrannon=upper Llandovery Series). Independent dating by chitinozoans has not been possible as their slides contain only Lagenochitina sp. and Bursachitina conica (Taugourdeau \& De Jekhowsky). They described 38 species of 'hystrichospheres' (now assigned to the acritarchs and prasinophyte algae), of which 20 were new. One of their illustrated specimens (Baltisphaeridium aff. polytrichium Valensi, pl. 3, figs 24-25) was subsequently designated as the holotype of Filisphaeridium (now Comasphaeridium) williereae Lister, 1970. Also, one of their taxa (Baltisphaeridium denticulatum) was subsequently designated as the type species of Diexallophasis Loeblich, 1970.

A study of Stockmans \& Willière's type material has shown that their original diagnoses and illustrations give little idea of the morphological complexity of many of their species. Therefore a re-description of the holotypes has been undertaken, together with a re-assessment of the original taxonomic assignments (and subsequent revisions) of their species. No emendations to the diagnoses have been proposed, as it is not possible to determine the morphological variability within each species from the type specimen alone. However, the detailed descriptions provided will enable researchers to recognize more accurately these species elsewhere, and they will also provide a basis for future population studies.

Stockmans \& Willière's type material is strongly thermally altered and some specimens are opaque to nearly opaque (e.g. O.? tenuiramusculosum). However, the preservation is otherwise generally good to excellent. Each slide generally contains only a low number of specimens, and this has negated the possibility of completing more detailed biometric or population variability studies. The mounting media on some of the slides has begun to degrade (air bubbles are forming beneath the coverslips), and all of the slides are heavily contaminated with elongate mineral laths (also visible on the original plates). It has not been possible to re-examine all of Stockmans \& Willière's holotypes, as several could not be located. The following taxa (all reported to be from their preparation 1179) are, therefore, not discussed here: Multiplicisphaeridium (was Baltisphaeridium) fissile (Stockmans \& Willière, 1963) Eisenack et al., 1973; Unellium (was Micrhystridium) flandrianum (Stockmans \& Willière, 1963) Sarjeant \& Vavrdova, 1997; Multiplicisphaeridium (was Micrhystridium) varians (Stockmans \& Willière, 1963) Eisenack et al., 1973; and Micrhystridium ornatum.

The diagnoses and illustrations of some species in Stockmans \& Willière (1963) fully described the morphological features present on the holotypes and these taxa are also not discussed here: Domasia (was Veryhachium) delmeri (Stockmans \& Willière, 1963) Umnova, 1975; Domasia (was Veryhachium) limaciforme (Stockmans \& Willière, 1963) Cramer, 1970 emend. Hill (1974); Micrystridium coronatum and Leiosphaeridia laevigata. The description and illustration of Buedingiisphaeridium parveroquesi here may be that of the holotype (it has not been possible to confirm this beyond all doubt), but at the least it is topotype material.

The dimensions referred to below are as follows (see also Mullins, 2001, text-fig. 13): V, vesicle diameter; V1, vesicle length; Vw, vesicle width; $\mathrm{Pl}$, process length; $\mathrm{P} \varnothing \mathrm{b}$. diameter of the process bases; PØt, diameter of the processes at the site of branching; Pn, number of processes. Specimens illustrated here are deposited in the collection of the Institut Royal des Sciences Naturelles de Belgique, Rue Vautier 29, B-1040 Brussells, Belgium.

\section{SYSTEMATIC TAXONOMY}

Buedingiisphaeridium parveroquesi (Stockmans \& Willière, 1963) comb. nov.

(Pl. 1, fig. 3)

1963 Micrhystridium parveroquesi Stockmans \& Willière: 471, pl. 2, fig. 10, text-fig. 33 . 

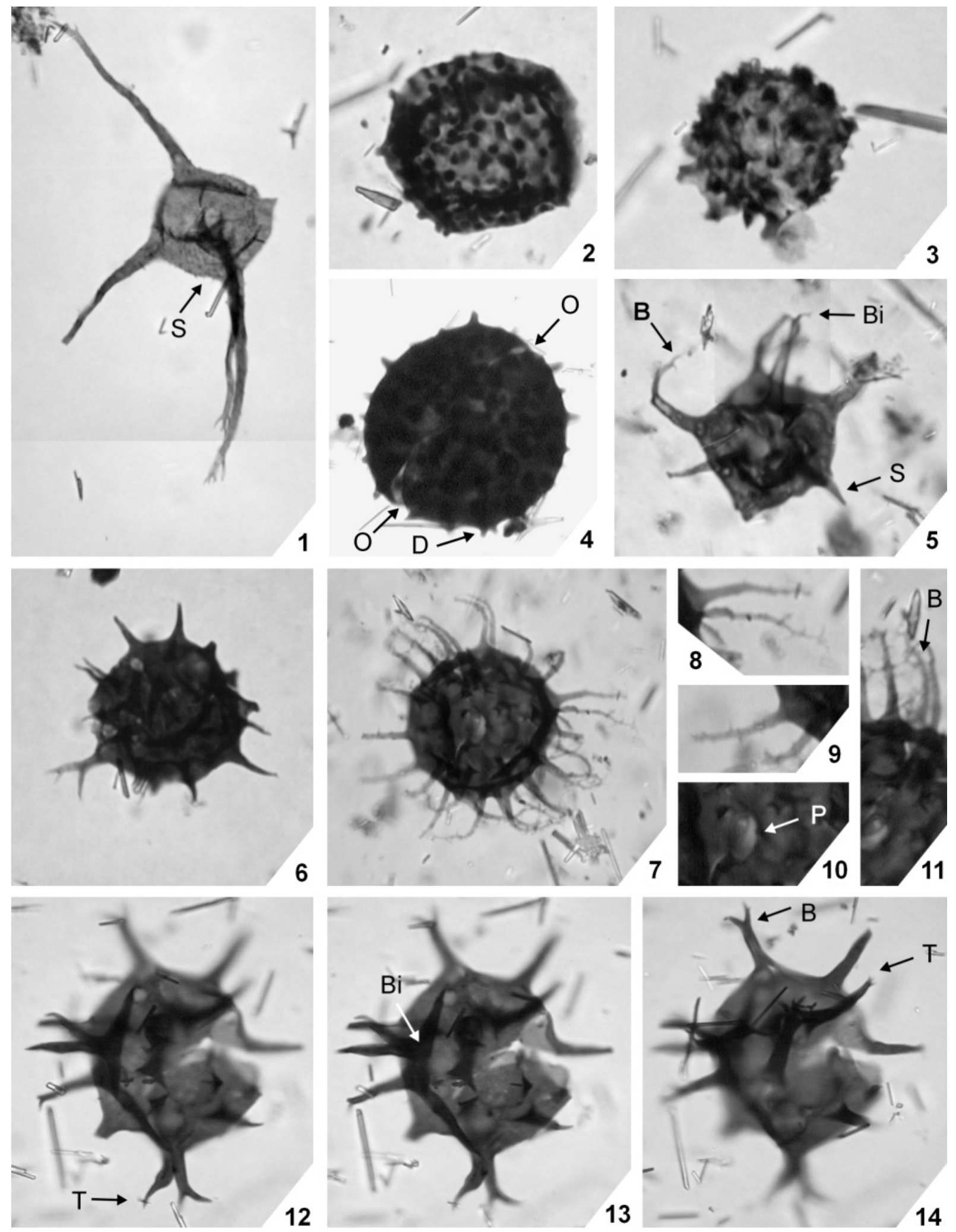
Description. Vesicle spherical with a slightly roughened surface. The vesicle is covered in projections, which may be entirely solid or have solid tips (Pn, c. 50). The projections may be bulbous, taper to a point, or they may be broad, parallel-sided and distally divaginate. No opening of the vesicle was observed.

Dimensions. V, $13.2 \mu \mathrm{m}$; Pl, 1-1.8 $\mu \mathrm{m}$; PØb, 0.7-1.5 $\mu \mathrm{m}$.

Remarks. This species, which was retained in Micrhystridium by Sarjeant \& Stancliffe (1994), is assigned to Buedingiisphaeridium as it has heteromorphic processes with a simple, bulbous, or distally divaginate appearance which may be entirely solid or have solid tips. These features conform to the emended diagnosis of Buedingiisphaeridium proposed by Sarjeant \& Stancliffe (1994). Species of Micrhystridium have simple processes which are hollow and open to the vesicle interior.

Comasphaeridium williereae (Deflandre \& Deflandre-Rigaud, 1965 ex Lister, 1970) Sarjeant \& Stancliffe, 1994

$$
\text { (P1. 2, fig. 5) }
$$

1963 Baltisphaeridium aff. polytrichium (Valensi); Stockmans \& Willière : 460, pl. 3, figs 24, 25, text-fig. 16 .

1994 Comasphaeridium williereae (Deflandre \& DeflandreRigaud, 1965 ex Lister, 1970); Sarjeant \& Stancliffe : 27.

Description. Vesicle spherical, laevigate, thin-walled. The vesicle is covered in numerous $(\mathrm{Pn},>100)$, solid, thin, columnar to slightly tapering processes, with simple, blunt, rounded tips. No opening in the vesicle was observed.

Dimensions. V, $25.8 \times 24.4 \mu \mathrm{m}$; Pl, 4.8-8 $\mu \mathrm{m}$; PØb, 0.3-1 $\mu \mathrm{m}$.

Remarks. The specimen of $B$. aff. polytrichium illustrated by Stockmans \& Willière is the holotype of $C$. williereae (as defined by Lister, 1970). The assignment of williereae to Comasphaeridium was proposed by Sarjeant \& Stancliffe (1994, pp. 27, 31, 67-68). An abbreviated synonymy is given above and a more complete history of the taxonomy and junior synonyms of $C$. williereae was given by Mullins (2001, p. 63).

\section{Dictyotidium deflandrei (Stockmans \& Willière, 1963) comb. nov.}

(Pl. 2, fig. 1)

1963 Leiosphaeridia deflandrei Stockmans \& Willière: 474-475, pl. 1, figs 2, 3 .
1987 Alveosphaera? deflandrei (Stockmans \& Willière, 1963); Priewalder: 23, pl. 1, figs 4, 5 .

Description. Vesicle spherical, fairly thick-walled (c. $1.7 \mu \mathrm{m})$, with a distinctive reticulate pattern. The reticulate pattern is produced by ellipsoidal to sub-hexagonal holes in the vesicle wall, or by fields with thin-walled floors. The fracture across the vesicle appears to be an artefact of preservation.

Dimensions. V, $30.7 \times 31.8 \mu \mathrm{m}$; holes, $0.6-1.3 \mu \mathrm{m}$.

Remarks. The reticulate pattern on the holotype appears to be produced by distinct holes or fields with thin-walled floors. It is probable that the holes (Pl. 2, fig. 1) are a result of preservation (produced by the destruction of the thin wall on the floor of each field) and that they do not represent a primary porous structure. Priewalder's assignment of this taxon to Alveosphaera?, a genus characterized by its porous vesicle wall, is therefore rejected and his taxon is assigned to the prasinophyte alga Dictyotidium.

Diexallophasis denticulata (Stockmans \& Willière, 1963) Loeblich, 1970

(P1. 2, fig. 7)

1963 Baltisphaeridium denticulata Stockmans \& Willière: 458, pl. 1, fig. 4, text-fig. 13.

1970 Diexallophasis denticulata (Stockmans \& Willière); Loeblich: 715, figs 8A-E, 9A-C.

1973 Multiplicisphaeridium denticulatum (Stockmans \& Willière, 1963); Eisenack et al.: 587-591.

Description. Vesicle single-walled, broadly ellipsoidal, although it does appear slightly polygonal in aspect. The processes $(\mathrm{Pn}, 7)$ are open to the vesicle. The vesicle is faintly ornamented (probably a microfoveolate or micropunctate ornament). The process bases are distinctly striate and these striae radiate out on to the vesicle surface for a short distance $(c .4 .5 \mu \mathrm{m})$. The processes are distinctly echinate along their length (echinae up to $1.1 \mu \mathrm{m}$ diameter). They are slightly tapering and all of the processes are broken before the distal extremities are reached. There is a lateral split in the vesicle wall which may represent an excystment structure, although the edges are roughened suggesting that it may be an artefact of preservation.

Dimensions. V, $35 \times 31 \mu \mathrm{m} ; \mathrm{Pl}$, at least $40.9 \mu \mathrm{m} ; \quad \mathrm{P} \varnothing \mathrm{b}$, $4.5-5.7 \mu \mathrm{m}$.

Explanation of Plate 1

Fig. 1. Diexallophasis mucronata (Stockmans \& Willière, 1963) Priewalder, 1987, holotype, preparation 1159, composite of three images showing the spinose vesicle ornament $(S), \times 1250$. Fig. 2. Lophosphaeridium parverarum Stockmans \& Willière, 1963, holotype, preparation $1172, \times 1500$. Fig. 3. Buedingiisphaeridium parveroquesi (Stockmans \& Willière, 1963) comb. nov., possible holotype (see above), preparation 1179 , $\times 2000$. Fig. 4. Lophosphaeridium parvum Stockmans \& Willière, 1963, holotype, preparation 1173, the edges of the linear rupture (O) and divaginate process (D) are shown, $\times 1250$. Fig. 5. Multiplicisphaeridium pentagonale (Stockmans \& Willière, 1963) comb. nov., holotype, preparation 1162, composite of three images showing the ramified branched (B), simple (S) and distally birfurcate $(\mathrm{Bi})$ processes, $\times 1500$. Fig. 6. Multiplicisphaeridium cortracumense (Stockmans \& Willière, 1963) Eisenack et al., 1973, holotype, preparation 1166, × 1500. Figs 7-11. Micrhystridium? radians Stockmans \& Willière, 1963, holotype, preparation 1162: 7, $\times 1250 ; 8$, close-up of a process where the spines give it an almost ramified appearance, $\times 2000$; 9, close-up of a blunt-tipped process with spines along its length, $\times 2000 ; \mathbf{1 0}$, view of the pylome $(\mathrm{P}), \times 2000$; 11, view of the ramified process branching (B), $\times 2000$. Figs 12-14. Multiplicisphaeridium snigirevskaiae (Stockmans \& Willière, 1963) Fensome et al., 1990, holotype, preparation 1178: 12, view of the distal trifurcate branching $(\mathrm{T}), \times 1250 ; \mathbf{1 3}$, view of the proximally bifurcate process $(\mathrm{Bi}), \times 1250 ; \mathbf{1 4}$, view of the ramified process branching (B) and distal, trifurcate branching $(\mathrm{T}), \times 1250$. 

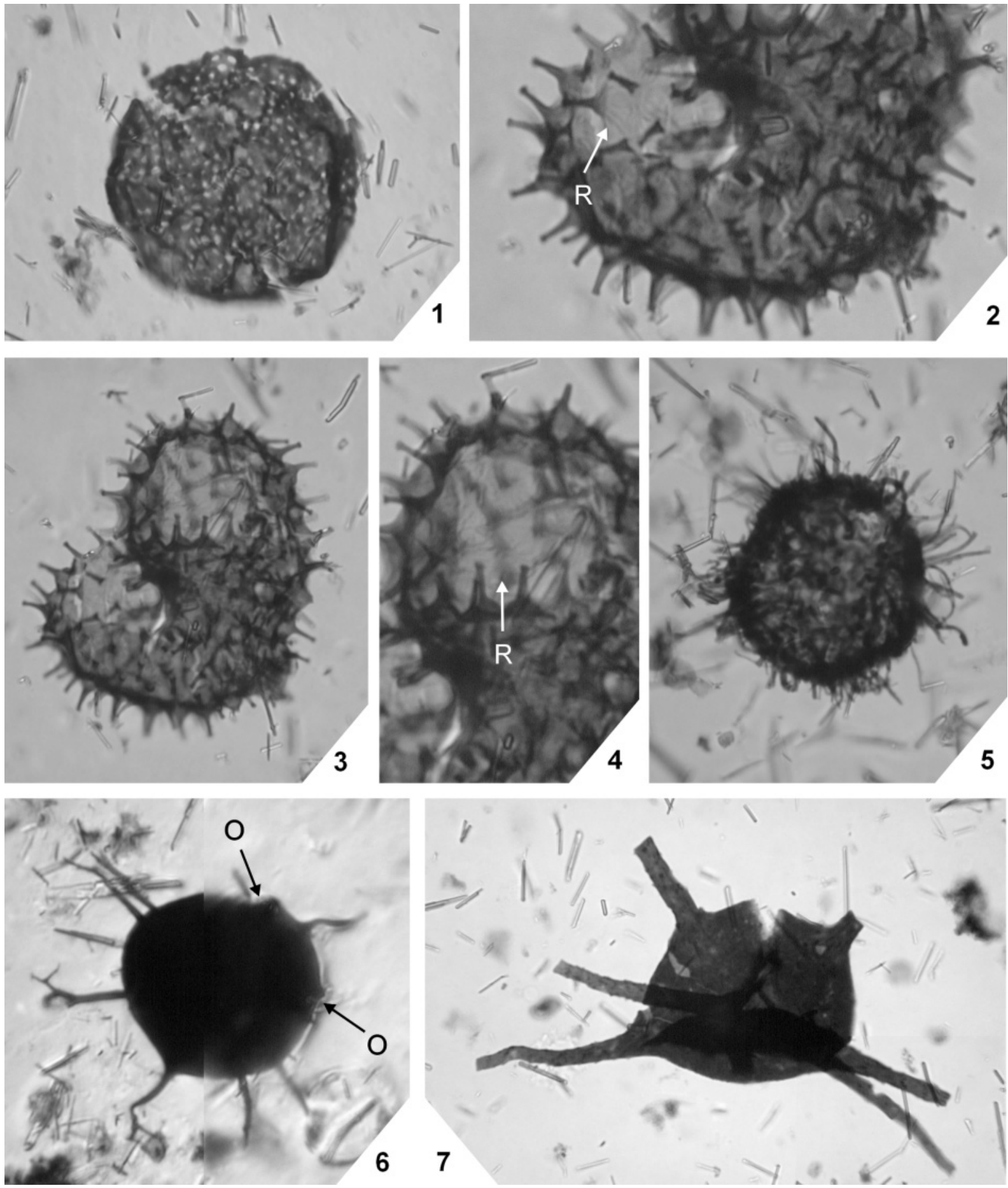

Explanation of Plate 2

Fig. 1. Dictyotidium deflandrei (Stockmans \& Willière, 1963) comb. nov., holotype, preparation 1160, × 1250. Figs 2-4. Helosphaeidium echinodermum (Stockmans \& Willière, 1963) comb. nov., holotype, preparation 1164: 2, rugulate ornament (R) radiating out from the process bases, $\times 2000$; 3, large linear rupture excystment opening, $\times 1250 ;$ 4, irregular rugulate ornament $(\mathrm{R}), \times 2000$. Fig. 5. Comasphaeridium williereae (Deflandre \& Deflandre-Rigaud, 1965 ex Lister, 1970) Sarjeant \& Stancliffe, 1994, holotype, preparation 1164, × 1250. Fig. 6. Oppilatala? tenuiramusculosum (Stockmans \& Willière, 1963) Priewalder, 1987, holotype, preparation 1156, composite of two images, edges of the excystment structure are shown $(\mathrm{O}), \times 1250$. Fig. 7. Diexallophasis denticulata (Stockmans \& Willière, 1963) Loeblich, 1970, holotype, preparation 1160 , composite of two images, $\times 1000$. 
Remarks. A detailed description of $D$. denticulata is provided to describe clearly the microfoveolate or micropunctate vesicle ornament. Unfortunately the broken nature of the processes means that the true nature of the branching is not known. $D$. denticulata was considered to be a junior synonym of Diexallophasis remota Deunff, 1955 by Playford (1977). This synonymy is rejected here as the processes of $D$. remota are broader-based and much more robust.

Diexallophasis mucronata (Stockmans \& Willière, 1963) Priewalder, 1987

(Pl. 1, fig. 1)

1963 Veryhachium mucronatum Stockmans \& Willière: pl. 1, fig. 20; pl. 3, fig. 6; text-figs 10-11.

1970 Baltisphaeridium mucronatum (Stockmans \& Willière, 1963); Cramer: 142, pl. 13, fig. 43d.

1973 Multiplicisphaeridium mucronatum (Stockmans \& Willière, 1963); Eisenack et al.: 695-697.

1987 Diexallophasis? mucronata (Stockmans \& Willière, 1963); Priewalder: 32, pl. 5, figs 3, 4.

1994 Frankea mucronata (Stockmans \& Willière, 1963); Sarjeant \& Stancliffe: 42.

1997 Villosacapsula mucronatum (Stockmans \& Willière, 1963); Sarjeant \& Vavrdova: 35.

Description. Square vesicle with convex sides and a single wall. The processes ( $\mathrm{Pn}, 5$ present +1 broken off) are open to the vesicle interior. Four processes are situated at each corner of the vesicle, and two processes arise from each side. The processes are long, thin, slender, slightly tapering, with a distinctly spinose form of digitate branching occurring at the very tip. Branching occurs up to the 2 nd order. The processes are sparsely ornamented with echinae along their length. The vesicle is densely ornamented with prominent spines or baculae of up to $1 \mu \mathrm{m}$ in length. No excystment opening is present.

Dimensions. V, $14.2 \times 16.1 \mu \mathrm{m}$; Pl, 27.3-28.4 $\mu \mathrm{m}$; PØb, $3.4 \mu \mathrm{m}$; PØt, $1.1 \mu \mathrm{m}$.

Remarks. The processes of D. mucronata have a distinctly spinose form of digitate branching and the vesicle has a dense, spinose or baculate ornament (Pl. 1, fig. 1). Priewalder (1987) transferred this species to Diexallophasis? and the assignment to Diexallophasis is confirmed here; the processes and vesicle are ornamented and the branching has the digitate style typical of that genus.

Sarjeant \& Stancliffe (1994) assigned mucronata to Frankea, a genus with a characteristic triangular vesicle. The vesicle of the holotype of D. mucronata is, however, square with convex sides (P1. 1, fig. 1).

Sarjeant \& Vavrdova (1997) assigned mucronata to Villosacapsula as 'there are only three long processes, branching and without a cover of denticles'. The re-examination of the holotype presented here clearly shows that there are six processes with a sparse covering of echinae along their length and the combination Villosacapsula mucronata is therefore rejected.
Helosphaeridium echinodermum (Stockmans \& Willière, 1963) comb. nov.

(P1. 2, figs 2-4)

1963 Baltisphaeridium echinodermum Stockmans \& Willière: 460-462, pl. 2, figs 5, 8; pl. 2, fig. 26; text-fig. 17-20.

1979 Gorgonisphaeridium echinodermum (Stockmans \& Willière, 1963); Eisenack et al.: 233-224.

1981 Salopidium? echinodermum (Stockmans \& Willière, 1963); Priewalder: 50-51, pl. 11, figs 9-12.

Description. Vesicle originally spherical to ellipsoidal, now almost separated into two equal halves by a large linear excystment opening which encircles the equator of the vesicle. The vesicle has a faint ornament of low rugulae which appear to either radiate out from the bases of the processes, or have an irregular distribution. The processes (Pn, c. 150) are hollow, open to the vesicle interior and taper to capitate tips, although some may possibly have small spines arising from their tips.

Dimensions. V, $29.5 \mu \mathrm{m}$; Pl, $3.5 \mu \mathrm{m}$; PØb, $1.1 \mu \mathrm{m}$.

Remarks. H. echinodermum has a spherical to ellipsoidal, singlewalled vesicle, numerous hollow processes (which freely communicate with the vesicle) and a large linear rupture type of excystment opening (all diagnostic features of Helosphaeridium; see Lister, 1970, p. 76). The processes of H. echinodermum appear capitate under transmitted light microscopy; species of Ammonidium have processes with a rosette arrangement of branches at the process tip. The holotype of H. echinodermum shows similarity to species of Hapsidopalla (e.g. H. jeandeunffii), but the rugulae are not well developed and they do not join adjacent processes as stipulated in the diagnosis of Hapsidopalla (see Playford, 1977, p. 25). The proposed assignment of echinodermum to Salopidium? and Gorgonisphaeridium (see above) are rejected, as species of those genera have entirely simple processes and solid processes respectively. The processes of $H$. echinodermum are capitate, hollow and open to the vesicle interior.

Lophosphaeridium parverarum Stockmans \& Willière, 1963 (Pl. 1, fig. 2)

1963 Lophosphaeridium parverarum Stockmans \& Willière: 473, pl. 3, fig. 21, text-fig. 35 .

Description. Vesicle ellipsoidal, with a slight polygonal aspect, and thinner-walled than the processes. The vesicle appears laevigate, with the exception of the numerous (Pn, c. 115), short processes (height $=0.9-1.4 \mu \mathrm{m})$. The processes are parallelsided, taper to rounded tips, or have a warty appearance. The processes are randomly distributed across the vesicle.

Dimensions. V, $19.5 \times 22.2 \mu \mathrm{m}$.

Remarks. Whereas Stockmans \& Willière (1963; text-fig. 35) showed the processes orientated into distinct rows, the description above highlights the random distribution of the processes.

\section{Lophosphaeridium parvum Stockmans \& Willière, 1963}

(P1. 1, fig. 4)

1963 Lophosphaeridium parvum Stockmans \& Willière: 472-473, pl. 2, fig. 2; pl. 3, fig. 27 , text-fig. 34 . 
Description. Vesicle spherical, near opaque, apparently smooth and covered in a random arrangement of processes which taper to simple, rounded tips. A single process appears to be proximally divaginate, although it has the rounded tips characteristic of the other processes. The processes are darker than the vesicle, suggesting that they are solid (although the specimen is too thermally altered to confirm this). The vesicle possesses a large, linear rupture excystment opening which almost divides the vesicle into two equal halves.

Dimensions. V, $26.7 \times 27.3 \mu \mathrm{m} ; \mathrm{Pl}, 0.7-2 \mu \mathrm{m} ; \mathrm{P} \varnothing \mathrm{b}, 1.2-2.3 \mu \mathrm{m}$.

Remarks. A description of the holotype is given here, as the possible proximal divaginate nature of the processes and large, linear, excystment opening were not reported by Stockmans \& Willière (1963, p. 472).

Micrhystridium? radians Stockmans \& Willière, 1963

(P1. 1, figs 7-11)

1963 Micrhystridium radians Stockmans \& Willière: 463, pl. 3, fig. 15; pl. 2, fig. 18; text-fig. 21.

1994 Comasphaeridium radians (Stockmans \& Willière, 1963); Sarjeant \& Stancliffe: 22.

Description. Vesicle laevigate, spherical overall, with a slight polygonal appearance produced by the straight to slightly concave nature of the vesicle between the processes. The processes are numerous ( $\mathrm{Pn}, c .49)$, slightly thinner-walled than the vesicle (which gives them a slightly lighter coloration), although they appear hollow and open to the vesicle interior. The processes are flexuous and taper slightly along their length. Some processes appear blunt-tipped with distinct spines (up to $1.7 \mu \mathrm{m}$ long) arising from their tips (giving them an almost branched appearance). The tips of others appear to branch in an almost ramified manner. The processes have a covering of elongate spines along their distal length (from about $1 / 2-1 / 3$ along the length of the process from the base). A small circular pylome $(2.8 \times 5.1 \mu \mathrm{m})$, with a thickened rim, is situated in the centre of the vesicle.

Dimensions. V, $20.4 \mu \mathrm{m}$; Pl, 13.6-17.6 $\mu \mathrm{m}$; PØb, $2.3 \mu \mathrm{m}$; PØt, up to $1 \mu \mathrm{m}$ wide (often much thinner).

Remarks. The assignment of radians to Comasphaeridium, proposed by Sarjeant \& Stancliffe (1994), is rejected as species of Comasphaeridium have thin, simple, solid, hair-like processes (see Staplin et al., 1965; Sarjeant \& Stancliffe, 1994). The spinose and occasionally branched nature of the processes, and presence of a circular pylome, were not discussed in the original diagnosis of Stockmans \& Willière (1963, p. 463). Their diagnosis stated only that the processes were simple. This species is provisionally retained in Micrhystridium, although it excysts via a pylome and therefore most probably represents an undescribed genus. However, as only a single specimen has been observed no new generic assignment can be proposed.

Some species of Micrhystridium possess a similar spinose process ornament to $M$.? radians (e.g. M. intonsurans), but the diagnosis of Micrhystridium stipluates that excystment occurs via a rupture, epityche or cryptosuture, not a pylome (see
Sarjeant \& Stancliffe, 1994, p. 12). Species of Uncinisphaera Wicander, 1974 are similar (they also have echinate processes), but excyst via a rupture. Species of Peteinosphaeridium Staplin et al., 1965 and Polyancistrodorus Loeblich \& Tappan, 1969 differ in possessing processes with longitudinal membranes along their length. The processes of Rhopaliophora Tappan \& Loeblich, 1971 are distinctly short and stout.

\section{Multiplicisphaeridium cortracumense (Stockmans \& Willière, 1963) Eisenack et al., 1973 \\ (P1. 1, fig. 6)}

1963 Micrhystridium cortracumense Stockmans \& Willière: 468 469, pl. 1, fig. 11; pl. 3, fig. 13?; text-fig. 29.

1973 Multiplicisphaeridium cortracumense (Stockmans \& Willière, 1963); Eisenack et al.: 579.

1997 Micrhystridium cortracumense Stockmans \& Willière, 1963; Sarjeant \& Vavrdova: 28.

Description. Vesicle spherical, dark, apparently laevigate. The processes $(\mathrm{Pn}, 27)$ are mostly simple, although a single process branches in a ramified manner to the 2 nd order. The tip of this process is noticeably lighter (thinner-walled) than the rest of the process or the vesicle. The processes are broad-based, laevigate, apparently open to the vesicle interior and taper distinctly. No opening was observed.

Dimensions. V, $16.1 \times 16.5 \mu \mathrm{m}$; Pl, 3.1-5.7 $\mu \mathrm{m}$; PØb, 1.1-1.7 $\mu \mathrm{m}$; PØt, $1.1 \mu \mathrm{m}$.

Remarks. This species was retained in Micrhystridium by Sarjeant \& Vavrdova (1997) on the basis that the majority of the processes are simple. However, the single process that does branch is ramified to the 2nd order (Pl. 1, fig. 6). This is a characteristic feature of species of Multiplicisphaeridium, and acritarchs with multifurcate tips were excluded from Micrhystridium by Sarjeant \& Stancliffe (1994, p. 12).

Multiplicisphaeridium pentagonale (Stockmans \& Willière, 1963) comb. nov.

(P1. 1, fig. 5)

1963 Micrhystridium pentagonale Stockmans \& Willière: 470-471, pl. 3, fig. 18, text-fig. 32.

1994 Micrhystridium? pentagonale (Stockmans \& Willière, 1963); Sarjeant \& Stancliffe: 18.

Description. Vesicle pentagonal, laevigate. The processes ( $\mathrm{Pn}, 7$ +2 broken off) are laevigate, open to the vesicle interior, straight or slightly flexuous, and taper distinctly from broad bases to either simple or branched tips (branching 1st order, possibly up to the 2nd order). No excystment opening was observed.

Dimensions. V, $15.1 \times 15.9 \mu \mathrm{m} ; \mathrm{Pl}, 9.8-12.2 \mu \mathrm{m} ; \mathrm{P} Ø \mathrm{~b}, 2.3 \mu \mathrm{m}$.

Remarks. Sarjeant \& Stancliffe (1994) noted the damage on the holotype of $M$. pentagonale and questionably retained it within Micrhystridium. The assignment of pentagonale to Multiplicisphaeridium is proposed as the holotype has processes which have ramified branching and distal bifurcations. 
Multiplicisphaeridium snigirevskaiae (Stockmans \& Willière, 1963) Fensome et al., 1990

(P1. 1, figs 12-14)

1963 Baltisphaeridium snigirevskaiae Stockmans \& Willière: 459460, pl. 1, fig. 5, text-fig. 15.

1970 Multiplicisphaeridium snigirevskaiae (Stockmans \& Willière, 1963); Lister: 84 (invalid combination, Lister did not clearly use the name $M$. snigirevskaiae).

1990 Multiplicisphaeridium snigirevskae (Stockmans \& Willière, 1963); Fensome et al.: 355.

1997 Unellium snigerevskaiae (Stockmans \& Willière, 1963); Sarjeant \& Vavrdova: 33.

Description. Vesicle polygonal (hexagonal), single-walled, laevigate. The processes $(\mathrm{Pn}, 14)$ are laevigate, open to the vesicle interior, simple or branched. The nature of the branching is variable. Some processes have a trifurcate arrangement of short spines at their very tip. One process bifurcates proximal to the vesicle surface. Processes may also be bifurcate or trifurcate in the last third of their length or at the very tip, and occasionally another subdivision is possible. The vesicle possess a linear rupture, although this is probably an artefact of preservation.

Dimensions. V, $22 \times 24.2 \mu \mathrm{m}$; Pl, 6.8-9.4 $\mu \mathrm{m}$; PØb, 2.2-2.5 $\mu \mathrm{m}$;

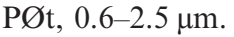

Remarks. A description of this species is given here to highlight the heteromorphic nature of the process branching. The processes may be ramified, distally trifurcate, or may even bifurcate proximal to the vesicle. Text-figure 15 of Stockmans \& Willière (1963) does not accurately reflect the distribution and nature of the processes on the holotype and it should not be relied upon.

The assignment of this species to Unellium by Sarjeant \& Vavrdova (1997) was based on the small size of the vesicle, the moderate number of processes and the distribution of the processes; Sarjeant \& Vavrdova considered the two poles of the vesicle to be occupied by enlarged, bifurcate processes. However, the processes on the holotype of $M$. snigerevskaiae are randomly distributed and the majority have distal trifurcate branches, with one being proximally bifurcate and one distally bifurcate (Pl. 1, figs 12-14). The assingment of snigerevskaiae to Unellium is therefore rejected.

Oppilatala? tenuiramusculosa (Stockmans \& Willière, 1963) Priewalder, 1987

(Pl. 2, fig. 6)

1963 Baltisphaeridium tenuiramusculosum Stockmans \& Willière: 457-458, pl. 3, fig. 9, text-fig. 12.

1965 Micrhystridium tenuiramusculosum (Stockmans \& Willière, 1963); Deflandre \& Deflandre-Rigaud: fiche 2491.

1973 Multiplicisphaeridium tenuiramusculosa (Stockmans \& Willière, 1963); Eisenack et al.: 807.

1981 Oppilatala? tenuiramusculosa (Stockmans \& Willière, 1963); Priewalder: 49-50, pl. 11, figs 1-4.

Description. Vesicle opaque, spherical, apparently laevigate. Thin, columnar to slightly tapering processes arise perpendicularly from a sharp contact with the vesicle. The processes are branched in a ramified manner (1st, 2nd or possibly even up to the 3rd order). The processes are laevigate. The edges of what may be an excystment opening can be seen (Pl. 2, fig. 6). It is not possible to determine the exact nature of the opening.

Dimensions. V, $22.7 \times 24.4 \mu \mathrm{m} ; \mathrm{Pl}, 8-11.9 \mu \mathrm{m}$; PØb, $1.3 \mu \mathrm{m}$; РØt, $0.6-1.3 \mu \mathrm{m}$.

Remarks. The holotype shows a possible excystment opening on the sides of the specimen (Pl. 2, fig. 6), and it appears to possess a plate-centred process and is suggestive of the operculate type of opening typical of Cymbosphaeridium. However, the vesicle is too opaque to confirm the nature of the opening with any certainty, and no further specimens of this taxon have been observed. This species is, therefore, retained in Oppilatala?, although the specimen is too opaque to confirm the presence of proximally plugged processes that are a characteristic feature of Oppilatala. However, the specimen does have processes which branch in a ramified manner (a feature common in Oppilatala), and it lacks the typical cauliflorate process branching of $\mathrm{Cym}$ bosphaeridium. The holotype is situated near an area affected by air bubbles forming beneath the cover-slip. However, these air bubbles do not extend as far as the specimen and the possible excystment opening is therefore not an optical illusion created by their presence.

\section{CONCLUSION}

The detailed descriptions of Stockmans \& Willière's holotypes provided will form the basis for future population studies and will enable the species to be recognized in contiguous sections elsewhere. This will help to highlight any potential biostratigraphical importance. Further work is required to ascertain the true generic affinity of Micrhystridium? radians.

\section{ACKNOWLEDGEMENTS}

This research was funded by the NERC (grant GR3/12838; awarded to R. J. Aldridge \& D. J. Siveter). I am also indebted to P. Bultynck and H. De Potter (Institut Royal des Sciences Naturelles de Belgique) for the loan of the material, and permission for its re-illustration. Thanks to S. G. Molyneux, R. J. Aldridge, D. J. Siveter, K. J. Dorning, W. A. S. Sarjeant and an anonymous referee for comments on some of the holotypes and the manuscript.

\section{Manuscript received 25 June 2001 Manuscript accepted 23 January 2002}

\section{REFERENCES}

Cramer, F.H. 1970. Distribution of selected Silurian acritarchs. Revista Espanola de Micropaleontologia, numero extraordinario, $1-202$.

Deflandre, G. 1945. Microfossiles des calcaires siluriens de la Montagne Noire. Annales de Paléontologie, 31: 41-75.

Deflandre, G. \& Deflandre-Rigaud, M. 1965. Fichier micropaléontologique général-Série 13. Acritarches II. Acanthomorphitae 1. Genre Micrhystridium Deflandre sens. lat. Archives originales, Centre de documentation, Centre National de la Recherche Scientifique, I-V, 402:, 2176-2521.

Deunff, J. 1955. Un microplancton fossile Dévonien a Hystrichosphères du Continent Nord-Américain. Bulletin de la microscopie applquée, sér. 2, 5:, 138-149. 
Eisenack, A., Cramer, F.H. \& Díez, M. del C.R. 1973. Katalog der fossilen Dinoflagellaten, Hystrichosphären und verwandten Mikrofossilien. Band III Acritarcha 1. Teil. E. Schweizertbart'sche Verlagsbuchhandlung, Stuttgart, 1-1104.

Eisenack, A., Cramer, F.H. \& Díez, M. del C.R. 1979. Katalog der fossilen Dinoflagellaten, Hystrichosphären und verwandten Mikrofossilien. Band V Acritarcha 2. Teil. E. Schweizertbart'sche Verlagsbuchhandlung, Stuttgart, 1-529

Fensome, R.A., Williams, G.L., Barss, M.S., Freeman, J.M. \& Hill, J.M. 1990. Acritarchs and fossil prasinophytes: An index to genera, species and intraspecific taxa. American Association of Stratigraphic Palynologists, Contribution Series, 25: 1-771.

Hill, P.J. 1974. Stratigraphic palynology of acritarchs from the type area of the Llandovery and the Welsh Borderland. Review of Palaeobotany and Palynology, 18: 11-23.

Lister, T.R. 1970. A monograph of the acritarchs and Chitinozoa from the Wenlock and Ludlow Series of the Ludlow and Millichope areas, Shropshire. Monograph of the Palaeontographical Society, publ. no. 528, part of vol. 124, 1-100.

Loeblich, A.R. 1970. Morphology, ultrastructure and distribution of Paleozoic acritarchs. Proceedings of the North American Paleontological Convention, Chicago, 1969, part G, 2: 705-788.

Loeblich, A.R. \& Tappan, H. 1969. Acritarch excystment and surface ultrastructure with descriptions of some Ordovician taxa. Revista Española de Micropaleontología, 1: 45-57.

Mullins, G.L. 2001. Acritarchs and prasinophyte algae of the Elton Group, Ludlow Series, of the type area. Monograph of the Palaeontolographical Society, publ. no. 615, part of vol. 155, 1-151.
Playford, G. 1977. Lower to Middle Devonian acritarchs from the Moose River Basin, Ontario. Geological Survey of Canada, Bulletin, 279: $1-87$.

Priewalder, H. 1987. Acritarchen aus dem Silur des Cellon-Profils (Karnische Alpen, Österreich). Abhandlungen der Geologischen Bundesanstalt, 40: 1-121.

Sarjeant, W.A.S. \& Stancliffe, R.P.W. 1994. The Micrhystridium and Veryhachium complexes (Acritarcha: Acanthomorphitae and Polygonomorphitae): a taxonomic reconsideration. Micropaleontology, 40: $1-77$.

Sarjeant, W.A.S. \& Vavrdova, M. 1997. Taxonomic reconsideration of Multiplicisphaeridium Staplin, 1961 and other acritarch genera with branching processes. Geolines (Praha), 5: 1-52.

Staplin, F.L., Jansonius, J. \& Pocock, S.A.J. 1965. Evaluation of some Acritarchous Hystrichosphere Genera. Neues Jahrbuch für Geologie und Paläontologie. Abhandlungen, 123: 167-201.

Stockmans, F. \& Willière, Y. 1963. Les Hystrichosphères ou mieux les Acritarches du Silurien Belge. Sondage de la Brasserie Lust à Courtrai (Kortrijk). Bulletin de la Société belge de géologie, de paléontologie et d'hydrologie, 71: 450-481.

Tappan, H. \& Loeblich, A.R. 1971. Surface sculpture of the wall in Lower Paleozoic acritarchs. Micropaleontology, 17: 385-410.

Umnova, N.I. 1975. Akritarkhi ordovika i silura Moskovskoi sineklizy i Pribaltiki. Izdatelskva Nedra, Moscow, 1-167.

Wicander, E.R. 1974. Upper Devonian-Lower Mississippian acritarchs and prasinophycean algae from Ohio, U.S.A. Palaeontographica, Abteilung B, 148: 9-43. 